\title{
Journal of Genetics Online Resources
}

\section{October - December 2015}

Gupta A. K., Chauhan M., Bhardwaj A. and Vijh R. K. 2015 Assessment of demographic bottleneck in Indian horse and endangered pony breeds. J. Genet. 94, e56-e62. Online only: http://www.ias.ac.in/jgenet/OnlineResources/94/e56.pdf

Costanzi J.-M., Mège P., Guérin S., Le Petitcorps Q., Carbonell A., Kouassi A. B. and Picard D. 2015 Characterization of nine new microsatellite loci for the marbled newt, Triturus marmoratus. J. Genet. 94, e63-e64. Online only: http://www.ias.ac.in/jgenet/OnlineResources/94/e63.pdf 